\title{
Pembuatan Sistem SMS Gateway Untuk Kelancaran Tagihan Pelanggan Di PT PLN Cabang Padang
}

\author{
Suardinata ${ }^{1}$, Amrin Lubis ${ }^{2}$ \\ ${ }^{1,2}$ Dosen STMIK Indonesia Padang \\ 노ardinata@gmail.com, ${ }^{2}$ maloebis@gmail.com
}

\begin{abstract}
ABSTRAK
Tagihan listrik oleh masyarakat, perusahaan, kantor, dan instansi sudah sejak lama menjadi masalah bagi perusahaan Negara yang terjadi di PT. PLN. Masalah ini dapat diperparah lagi dengan bertambahnya pengguna listrik yang semakin hari semakin meningkat seiring berkembangnya perumahan, perkantoran, industri dan pemukiman penduduk di Indonesia. Lambat laun ini akan menambah beban masalah baru dan akan menyulitkan PT. PLN dalam menangani tagihan yang harus dibayar pelanggan setiap bulannya. Dengan masalah yang sudah dialami oleh PT. PLN saat ini misalnya, semakin banyaknya pelanggan yang menunggak, bahkan tunggakan tagihan ini sampai berbulan-bulan. Hal ini biasa disebabkan oleh karena kelalaian atau karena kelupaan masyarakat pengguna listrik tersebut untuk membayar tagihan listriknya setiap bulan. Jika masalah ini dibiarkan terus menerus, mengakibatkan PT.PLN selalu mengalami kerugian setiap bulannya, hal ini akan mempengaruhi dan akan berdampak buruk terhadap kinerja pegawai PLN secara keseluruhan. Pada saat ini perkembangan teknologi informasi yang seharusnya sudah mampu untuk menyelesaikan segala masalah yang dihadapi terutama pada PT. PLN, namun kenyataan yang terjadi dilapangan penggunaan teknologi ini belum optimal dan kadang malah menambah masalah baru bagi penggunanya sendiri. Penggunaan teknologi informasi, misalnya teknologi SMS (Short Message Service) gateway yang menggunakan handphone adalah sangat popular, sudah menjadi trend dan sudah disentuh oleh kalangan pebisnis terutama dikalangan pebisnis telekomunikasi dan juga oleh masyarakat umum. Dalam kajian ini peneliti akan mencoba mengkaji teknologi SMS gateway untuk mengatasi masalah yang terjadi di PT. PLN yang mana ini akan diterapkan pada PT.PLN tersebut dalam rangka memberikan pelayanan dan menyampaikan informasi yang cepat, tepat dan akurat kepada masyarakat pengguna listrik secara umum, supaya pelanggan selalu ingat untuk membayar tagihan listriknya dan terhindar dari denda dan pemblokiran pemakaian listrik setiap bulan.
\end{abstract}

Keywords : Information technology,, electric bills, SMS gateway and mobile

\section{PENDAHULUAN}

Pertambahan perumahan, perkantoran, dinas, instansi dan pemukiman penduduk yang semakin hari semakin meningkat, dapat menjadi masalah baru bagi perusahaan yang berhubungan dengan masyarakat. PT. PLN adalah sebuah perusahaan yang bergerak dibidang kelistrikan, yang merupakan sebuah perusahaan yang menyediakan infrastruktur umum yang melayani kebutuhan pelanggan untuk penerangan dan sumber energi atau daya bagi perumahan, perkantoran, dinas, instansi, industry dan pemukiman penduduk. 
Kebutuhan akan listrik yang meningkat, ini akan mempengaruhi dan menimbulkan masalah baru dalam hal tagihan bulanan yang harus segera mungkin diatasi oleh PT. PLN. Dalam penelitian ini kami mengambil kasus yang terjadi di Wilayah Sumatera Barat. Dalam melayani pembayaran tagihan selama ini, PT. PLN selalu kewalahan dengan tagihan yang selalu membengkak setiap bulan dan ini pada akhirnya menyulitkan PT. PLN dalam melayani tagihan bulanan dari para pelanggan.

Saat ini layanan untuk pembayaran tagihan listrik sudah bisa dilakukan secara online, dimana pembayaran bisa dilakukan diloket PLN seluruh Indonesia, ditempat kioskios yang ada pada masyarakat, dan juga dapat dilakukan melalui bank yang ada di seluruh Indonesia. Namun hal ini masih belum bisa berjalan dengan optimal, disebabkan oleh ketidaktahuan pelanggan terhadap jenis layanan tersebut. Secara umum pelanggan kadang lupa dan tidak mengetahui tanggal deadline pembayaran, batas tanggal dikenakan denda. Hal ini bisa saja dikarenakan sibuk, belum cukup uang, tidak mengetahui jumlah pasti tagihan dan lain-lain.

Dengan masalah yang sudah dialami oleh PT. PLN saat ini misalnya, semakin banyaknya pelanggan yang menunggak, bahkan tunggakan tagihan ini sampai berbulanbulan. Hal ini biasa disebabkan oleh karena kelalaian atau karena kelupaan masyarakat pengguna listrik tersebut untuk membayar tagihan listriknya setiap bulan. Jika masalah ini dibiarkan terus menerus, mengakibatkan PT.PLN selalu mengalami kerugian setiap bulannya, hal ini akan mempengaruhi dan akan berdampak buruk terhadap kinerja pegawai PLN secara keseluruhan sebagaimana juga yang pernah diteliti oleh Ali Mustofa, et al, 2012.

Teknologi informasi yang sudah berkembang memberikan trend penyebaran informasi bukan hanya penyampaian dari mulut-kemulut maupun media surat, tetapi melalui media handphone. Hal ini dikarenakan handphone sudah merupakan kebutuhan primer dan selalu melekat kemanapun pemiliknya pergi. Teknologi termurah yang ada saat ini dengan jangkauan luas memungkinkan penyebaran informasi hanya melalui handphone. Oleh karena itu dan mudahnya pengoperasiannya sangat mendukung pekerjaan ini dilakukan oleh bagian administrasi PT. PLN kepada pelanggan dan calon pelanggannya.

Seiring dengan meningkatnya pengguna listrik di Indonesia maka perusahaan harus meningkatkan pelayanan dan penyampaian informasi yang cepat dan efisien. Dengan perkembangan teknologi di bidang informasi dan komunikasi serta adanya penemuan-penemuan baru saat ini menghasilkan banyak kemajuan serta perubahan dalam kehidupan, salah satu contoh perkembangan teknologi informasi adalah Short Message Service (SMS) Gateway dengan teknologi ini untuk menyampaikan informasi seperti tanggal jatuh tempo, jumlah tagihan listrik yang dibebankan kepada pelanggan. Short Message Service (SMS) Gateway merupakan gabungan dari teknologi sistem informasi dan sistem pengiriman pesan sederhana yang disediakan oleh jaringan handphone yaitu Short Message Service (SMS) Komputer merupakan suatu alat yang dapat membantu manusia dalam mengolah data untuk menghasilkan informasi.

Diharapkan dengan teknologi ini PT. PLN dapat mengirimkan informasi jatuh tempo atau pembayaran paling lambat kepada pelanggan dengan mengirimkan SMS (short message service) berupa tagihan yang harus dibayar setiap bulannya, sehingga pelanggan mengetahui berapa tagihan listriknya setiap bulan dan bisa terhindar dari denda dan pemblokiran pemakaian listrik yang diberikan oleh PT. PLN.

\subsection{Perumusan Masalah}

Berdasarkan latar belakang masalah diatas maka dapat dirumuskan masalah sebagai berikut: 
1. Bagaimana memberikan informasi kepada pelanggan listrik sedini mungkin, untuk menghindari dari denda dan pemblokiran pemakaian listrik.

2. Bagaimana mengetahui tagihan pelanggan dengan menggunakan handphone dari rumah, kantor, industry dan pemukiman pelanggan yang tersebar menjadi tantangan untuk mendapat informasi sesegera mungkin.

3. Bagaimana mengetahui pelanggan yang menunggak dan tidak menunggak supaya dapat menjadi bahan analisis bagi pimpinan PT. PLN.

\section{TINJAUAN PUSTAKA}

\subsection{Pengertian Sistem}

Sebagaimana dikatakan oleh Jogiyanto (2008, hal : 34) "Suatu sistem dapat didefinisikan sebagai kumpulan komponen yang saling berhubungan yang membentuk satu kesatuan untuk mencapai tujuan tertentu." Dan juga dijelaskan dalam bukunya Sistem Informasi Manajemen, Mc. Leod (2004, 9) sistem adalah sekelompok elemen-elemen yang terintegrasi dengan maksud yang sama untuk mencapai suatu tujuan. Sistem adalah sekumpulan dari elemen yang saling berhubungan atau berinteraksi hingga membentuk satu kesatuan, selain itu sistem juga dapat diartikan sebagai sekelompok komponen yang saling berhubungan dan bekerjasama untuk mencapai tujuan bersama dan menerima input serta menghasilkan output dalam proses transformasi yang teratur.

Dari penjelasan tersebut dapat disimpulkan bahwa sistem adalah satu kesatuan yang terdiri dari dua atau lebih komponen atau subsistem yang berinteraksi untuk mencapai suatu tujuan. Suatu sistem dapat terdiri dari sistem-sistem bagian (subsistem). Subsistem saling berinteraksi dan saling berhubungan membentuk satu kesatuan sehingga suatu tujuan atau sasaran sistem tersebut dapat tercapai.

\subsection{Pengertian Informasi}

Informasi adalah data yang telah diolah menjadi sebuah pengetahuan yang langsung berguna bagi yang memilikinya atau dapat dikatakan sebagai hasil dari pengolahan data yang dapat berfungsi untuk mencapai suatu tujuan tertentu atau untuk analisa dalam pengambilan keputusan.

Jogiyanto H.M (Teknologi Sistem Informasi, 2008, hal 36), "Informasi dapat didefenisikan sebagai data yang diolah menjadi bentuk yang berguna bagi para pemakai”.

\subsection{Pengertian Sistem Informasi}

Jogiyanto H.M (Teknologi Sistem Informasi, 2000, hal : 697). "Sistem informasi dapat didefenisikan sebagai suatu sistem didalam suatu organisasi yang merupakan kombinasi dari orang-orang, fasilitas, teknologi, media, dan pengendalian yang ditujukan untuk mendapatkan jalur komunikasi penting, memproses tipe transaksi rutin tertentu, memberi sinyal kepada manajemen dan yang lainnya terhadap kejadiankejadian internal dan eksternal yang penting dan menyediakan suatu dasar informasi untuk pengambilan keputusan".

Sistem Informasi merupakan sistem pembangkit informasi. Dengan integrasi yang dimiliki antar sub sistemnya, sistem informasi akan mampu menyediakan informasi yang berkualitas, tepat, cepat dan akurat sesuai dengan manajemen yang membutuhkannya. (Teguh Wahyono, 2008 : Akses 08 April 2012)

\subsection{Pengertian Data}

Data adalah bentuk jamak dari datum yang berarti fakta atau bahan-bahan keterangan yang mengandung arti yang dihubungkan dengan kenyataan, simbol-simbol, gambargambar, kata-kata, angka-angka, atau hurufhuruf yang menunjukkan suatu kode, objek, kondisi, atau situasi. Data berfungsi sebagai bahan dasar yang objektif (relatif) di dalam proses penyusunan kebijaksanaan dan keputusan pimpinan organisasi.

\subsection{Pengertian Teknologi Informasi} Menurut kamus Oxford (1995), teknologi informasi adalah studi atau penggunaan peralatan elektronika, terutama komputer, untuk menyimpan, menganalisa, 
dan mendistribusikan informasi (kata, bilangan, gambar). Sistem informasi dapat didefinisikan sebagai suatu sistem yang mencakup sejumlah komponen (manusia, komputer, teknologi informasi, prosedur kerja, dll), ada sesuatu yang diproses (data menjadi informasi), dan dimaksudkan untuk mencapai suatu sasaran atau tujuan. Adapun teknologi informasi merupakan bagian dari sistem informasi, yaitu salah satu sub-sistem dalam sistem informasi. Teknologi informasi mencakup perangkat keras dan lunak untuk melaksanakan satu atau sejumlah tugas pemrosesan data (menangkap, mentransmisi, menyimpan, mengambil, memanipulasi, atau menampilkan data), juga mencakup teknologi komunikasi untuk mengirimkan informasi. Teknologi informasi ini dapat berbagai macam bentuknya, antara lain, mikrokomputer, komputer mainframe, pembaca barcode, software transaksi, lembar kerja (spreadsheet), alat komunikasi, dan jaringan. Sistem informasi yang melibatkan komputer ini biasanya dikenal dengan sebutan sistem informasi berbasis komputer (Computer Based Information System/CBIS). Dengan demikian cakupan sistem informasi sangat luas dan cukup komprehensif untuk menunjang pengembangan suatu maksud/tujuan, termasuk dalam bidang kajian ilmu pengetahuan lain.

\subsection{Penggunaan Teknologi informasi}

Pemanfaatan teknologi informasi dalam mendorong kemajuan pembangunan suatu negara sudah tidak diragukan lagi. Penggunaan teknologi informasi sudah diimplemantasikan dalam segala bidang dan organisasi baik sektor formal, informal, pemerintahan dan industri dalam menunjang kinerja organisasi. Dalam penggunaannya keberhasilan teknologi informasi juga ditentukan oleh faktor teknis seperti infrastruktur dan faktor non teknis seperti prilaku dan sikap pengguna dalam penerimaan teknologi informasi.

Menurut $\mathrm{Hu}$ et al (2003) terdapat enam faktor yang mempengaruhi seseorang dalam penerimaan sebuah teknologi yaitu effikasi diri, relevansi pekerjaan, kesesuaian dengan teknologi, sikap/persepsi kemudahan dalam penggunaan, persepsi terhadap manfaat dan persepsi subjektif terhadap teknologi.

Seiring dengan perkembangan penelitian berkaitan penerimaan pengguna terhadap teknologi informasi dapat diketahui sejauhmana tahap penggunaan teknologi informasi pada suatu organisasi. Penelitian yang dilakukan Musa Abu Hasan (2008) tentang penggunaan teknologi informasi dalam kalangan pegawai pemerintahan di Malaysia mendapati bahwa terdapat perbedaan yang mencolok tahap penerimaan dan penggunaan teknologi di daerah perkotaan dan pedesaan. Faktor teknis seperti kesediaan infrastruktur dan sikap pengguna merupakan faktor yang mempengaruhinya. Tahap penggunaan pegawai pemerintah diperkotaan lebih tinggi dibanding pegawai pemerintah daerah. Selanjutnya penelitian Musa Abu Hasan et all (2012) mendapati faktor yang mempengaruhi penggunaan teknologi informasi dalam kalangan pegawai pemerintah di daerah adalah sikap pengguna dalam penggunaan, relevansi bidang pekerjaan, efikasi diri, kemudahan dalam penggunaan dan persepsi subjektif.

\subsection{SMS Gateway}

\subsubsection{SMS (Short Message Service)}

Short Message Service (SMS) adalah salah satu tipe Instant Messaging (IM) yang memungkinkan user untuk bertukar pesan singkat kapanpun, walaupun user sedang melakukan call data/suara. SMS dihantarkan pada channel signal GSM (Global System for Mobile Communication) (Sanggala, 2007). SMS juga digunakan pada teknnologi GPRS dan CDMA. SMS menjamin pengiriman pesan oleh jaringan, jika terjadi kegagalan pesan akan disimpan dahulu dijaringan, pengiriman paket SMS bersifat out of band dan menggunakan bandwidth rendah. bentuk 
teks dengan panjang maksimal sebanyak 160 karakter untuk alfabet latin dan 70 karakter untuk alfabet non latin, seperti : alfabet Arab atau Cina. Ada satu hal yang sangat menarik dari layanan ini, yaitu tarif yang relatif murah untuk setiap kali pengiriman pesan, bahkan hampir sama dengan pengiman sms biasa.

Sedangkan yang dimaksud dengan SMS Gateway adalah merupakan program aplikasi yang menghubungkan antara semua SMS yang dikirim dan diterima ke sebuah PC dengan menggunakan jaringan GSM. Bagian ini berfungsi membaca SMS dari Message Service (MS), mengirimkannya kembali SMS balasan ke pada yang meng akses nya. Jaringan GSM yang terintegerasi dengan layanan SMS memiliki tambahan subsistem.

\subsubsection{Sistem Kerja SMS}

Salah satu jasa layanan dari perusahaan operator telepon selular Global System for Mobile Communication (GSM) dan Code Division Multiple Access (CDMA) adalah Short Message Service. Dengan sarana ini maka telepon selular dapat menerima dan mengirimkan pesan-pesan pendek dengan

\section{TUJUAN DAN MANFAAT PENELITIAN}

\subsection{Tujuan Penelitian}

Tujuan penelitian ini membantu PLN

Cabang Padang untuk memonitoring:

1. Untuk memberikan informasi kepada pelanggan listrik sedini mungkin, untuk menghindari dari denda dan pemblokiran pemakaian listrik.

2. Untuk mengetahui tagihan pelanggan dengan menggunakan handphone dari rumah, kantor, industry dan pemukiman pelanggan yang tersebar menjadi tantangan untuk mendapat informasi sesegera mungkin.

3. Untuk mengetahui pelanggan yang menunggak dan tidak menunggak supaya dapat menjadi bahan analisis bagi pimpinan PT. PLN.

\subsection{Tujuan Khusus}

Adapun tujuan khusus dari penelitian ini adalah untuk mengikuti program DIKTI yaitu Hibah bersaing penelitian untuk dosen pemula.

\section{METODE PENELITIAN}

\subsection{Laboratory Research}

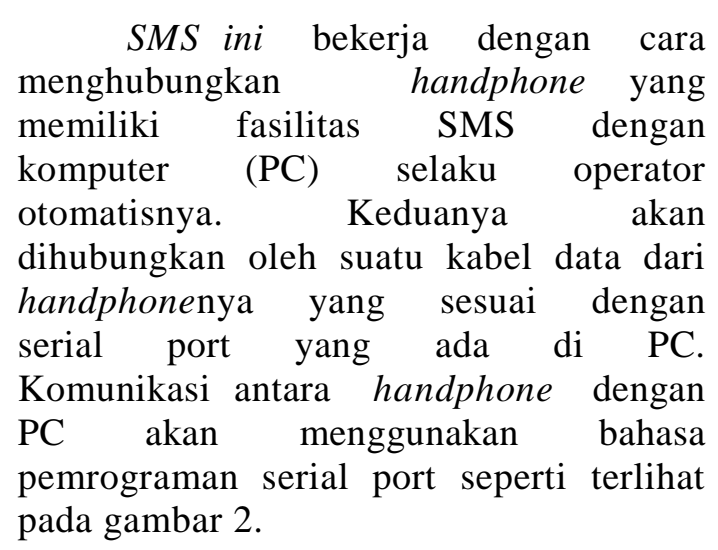

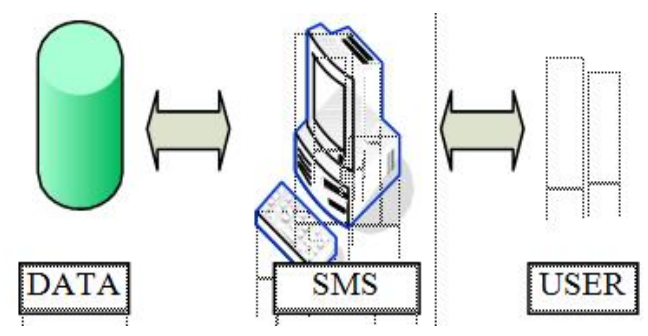

Gambar.1: Arsitektur SMS Gateway

\section{Basic Feature SMS}

SMS mempunyai beberapa basic feature, seperti :

1. Message Submission and Delivery

Terdiri dari Message Sending dan Message Delivery. Pada message sending, pesan dikirim dari MS ke SMSC, dialamatkan ke SME lain sebagai mobile user lain atau host internet. Originator (asal) SME menentukan validity period dari pesan tersebut, pesan yang sudah tidak valid lagi akan 
dihapus oleh SMSC sepanjang pengiriman pesan. Fitur ini dikenal sebagai Short Message-Mobile Originated (SM-MO). Pada message delivery, pesan disampaikan oleh SMSC ke MS. Dikenal sebagai Short Message Mobile Terminated (SM-MT). SM-MO dan SM-MT dapat dikirim / diterima saat voice call atau koneksi data sedang berlangsung.

2. Status Report

SME asal (Originator) meminta status report pada pengiriman pesan singkat $\mathrm{k}$ SME penerima (recipient). Status report memberikan indikasi pada user asal apakah pesan terkirim dengan sukses atau tidak kepada SME penerima.

3. Reply Path

Replay Path dapat diatur oleh SME asal (atau SMSC serving) untuk mengindikasikan bahwa SMSC serving dan mampu untuk menghandle secara langsung reply dari SME penerima.

\subsection{Metodologi Perancangan Sistem Informasi}

Kegiatan yang berkaitan dengan pembuatan Sistem Informasi ini seperti yang tergambar pada bab pendahuluan, memiliki banyak keragaman data, sumber data yang berbeda, dan kelompok data yang bermacammacam. Dari gambaran itu tentu ada keterkaitan data dan keperluan data antar bagian-bagian didalamnya dan diluar instansi. Untuk melakukan pendekatan terhadap masalah, tahapan analisis, evaluasi, dan perancangan bahkan sampai pada pemeliharaan, agar didapatkan desain database dan system informasi yang optimal diperlukan sebuah methodology yang menjadi acuan bagi System analyst, programmer dan End User. Metodology ini kemudian, yang dipakai sebagai acuan dalam membangun Sistem Informasi pemberitahuan tagihan listrik kepada pelanggan cabang Padang menggunakan handphone yang disebut System Development Life Cycle (SDLC). Methodology ini memjelaskan urutan pekerjaan, tahap demi tahap secara sistematis.
Pendekatan pada methodology ini, dimulai dari identifikasi dan memilih proyek (dalam lingkup kecil atau module), menetapkan dan merencanakan proyek, analisis (menentukan kebutuhan, menstrukturisasi keperluan, generate alternative yang dipilih), membuat desain logik, membangun desain pisik, dan melakukan implementasi dan pemeliharaan.

Dari gambar SDLC dibawah ini menjelaskan urutan pekerjaan yang dilalui untuk membangun sebuah management information system. System analyst dan team memulai pekerjaan mengidentifikasi masalah dan memilih proyek, menetapkan dan merencanakannya, analis, disain logic, disain pisik, implementasi dan pemeliharaan.

Dari gambar.2 berikut ini dapat dijelaskan lebih lanjut. Bila pekerjaan team pada setiap tahapan yang dilalui sukses, maka team dapat melanjutkan ketahapan berikutnya. Namun bila pada tahapan tertentu team menemukan ada kejanggalan atau masalah, urutan kerja team dapat mundur satu atau beberapa tahap kebelakang sampai ditemukan penyelesaiannya. Setiap tahapan dari SDLC, team berusaha mendiskusikan masalah yang dihadapi dengan end user atau pemakai system informasi, kemudian menggunakan tools analysis untuk merangkumnya dalam bentuk diagram.

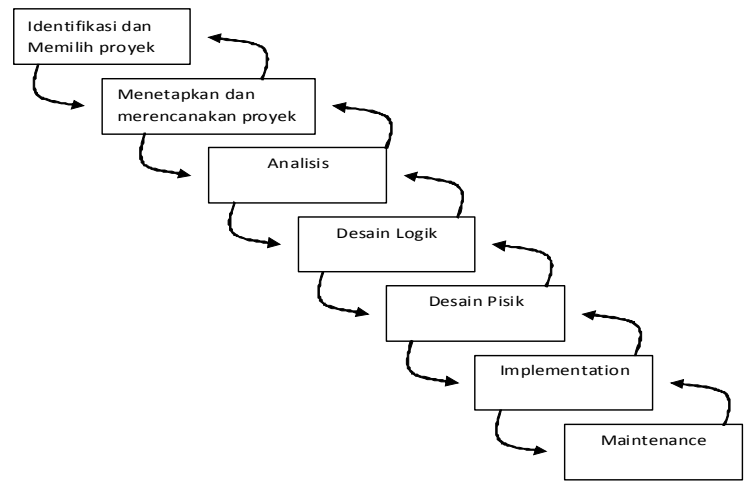

Gambar.2. System Development Life Cycle (Hoffer, et al, 2005) 
Team berusaha menenali boundary system, menghimpun data interact antar bagian-bagian yang terkait, dan menetapkan major information yang diperlukan antar bagian-bagian tersebut. Pendekatan seperti ini disebut top-down approach. Team berusaha mencari tahu dari end user laporan utama apa yang diperlukan, kemudian membuat turunanannya, dari dokumen-dokumen mana laporan utama ini bersumber, dan kepada siapa diberikan.

Tools analysis yang digunakan diantanya data flow diagram, dan entity relationship diagram. Disini team menggambarkan dan mempresentasikan Sistem Informasi yang telah dirancang di depan end user. Tujuannya menyamakan presepsi tentang model Sistem Informasi yang diusulkan dan menerima masukan dari audience. Bila model yang diajukan disepakati, team melakukan coding, testing sampai akhirnya implementasi.

\section{HASIL DAN PEMBAHASAN}

Sistem ini dibuat dengan tujuan memudahkan bagian informasi dan administrasi di PLN Kota Padang dalam memberikan pelayanan kepada pengguna listrik yang ada di kota Padang. Dalam penelitian ini, aplikasi yang dihasilkan baru mampu menangani dan memberikan informasi berapa tagihannnya tiap bulan kepada para pelanggan PLN yang ada di kota Padang. Yang mana kota Padang terdiri-dari 11 Kecamatan dibagi kedalam phone group name sebagai mana berikut:

Tabel 1: Nama phone group pelanggan yang ada di Kota Padang.

\begin{tabular}{|l|l|}
\hline No & \multicolumn{1}{|c|}{ Phone Group Name } \\
\hline 1 & Kecamamatan Koto Tangah \\
\hline 2 & Kecamatan Padang Selatan \\
\hline 3 & Kecamatan Padang Utara \\
\hline 4 & Kecamatan Padang Barat \\
\hline 5 & Kecamatan Pauh \\
\hline 6 & Kecamatan Bungus Teluk Kabung \\
\hline
\end{tabular}

\begin{tabular}{|l|l|}
\hline 7 & Kecamatan Kuranji \\
\hline 8 & Kecamatan Lubuk Begalung \\
\hline 9 & Kecamatan Lubuk Kilangan \\
\hline 10 & Kecamatan Nanggalo \\
\hline 11 & Kecamatan Padang Timur \\
\hline
\end{tabular}

Adapun berikut ini adalah gambaran aplikasi secara umum dapat dilihat sebagai berikut:

1. Administrator masuk kedalam system dengan memasukkan user name dan password kemudian tampilan menuju ke halaman home

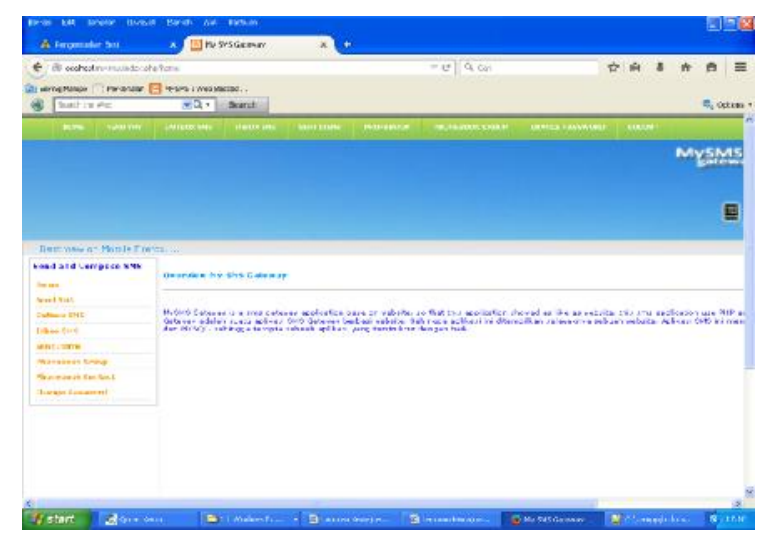

\section{Gambar 3. Halaman Home dari pada Aplikasi SMS Gateway}

2. Halaman home berisi sub menu diantaranya adalah : Home, send sms, outbox SMS, Inbox SMS, Sent Items, Phone Group, Phonebook Contact dan Change Password dan Logout seperti yang ditampilkan gambar diatas. .

3. Setelah itu jika di klik menu sent sms tampil dialog seperti digambarkan berikut ini 


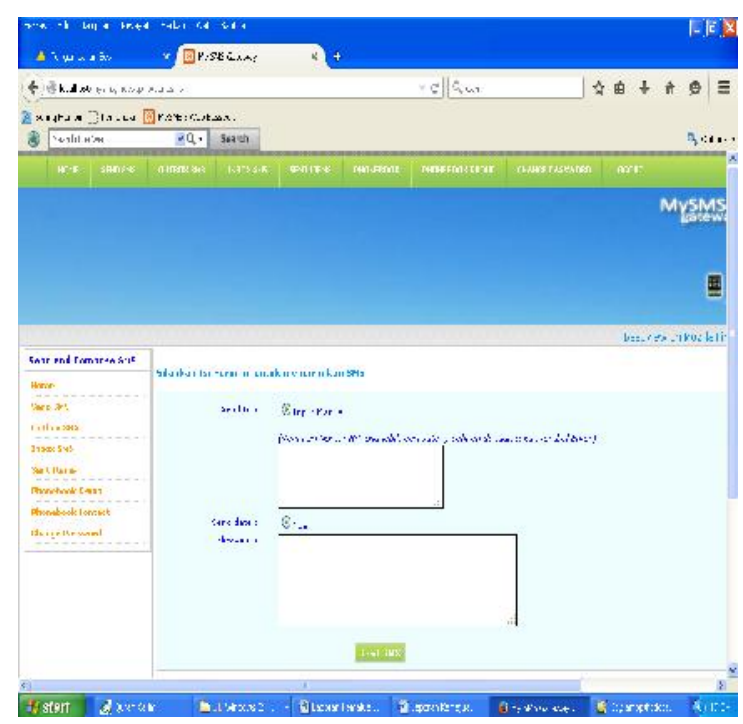

Dalam box dialog diatas terdapat 2 isian form Send to: dimana ini adalah digunakan untuk form inputan no Handphone yang akan di tuju dan Message yang mana ini digunakan untuk menuliskan pesan No Rekening, dan Total biaya tagihan.

Informasi biaya tagihan diambil dari websitenya PLN atau sms center dari PT. PLN Padang yaitu http: http://www.pln.co.id/sumbar/ dan juga dari Isms 8123 atau call centre 123

\section{Gambar 4. Halaman Send to dan Message dari pada Aplikasi SMS Gateway}

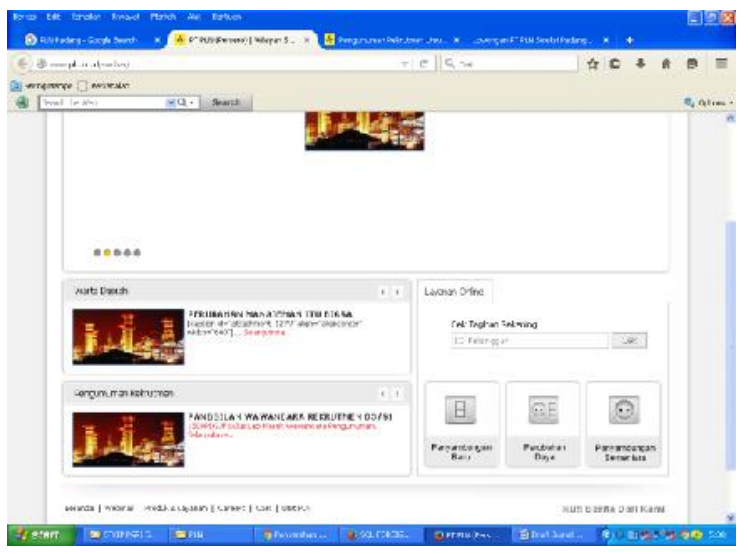

Gambar 5. Halaman Home dari pada Aplikasi PT. PLN Sumbar
Pada halaman home PT. PLN SUMBAR ini admin bisa melihat jumlah tagihan pelanggan yang ada pada kecamatan-kecamatan yang ada di Kota Padang

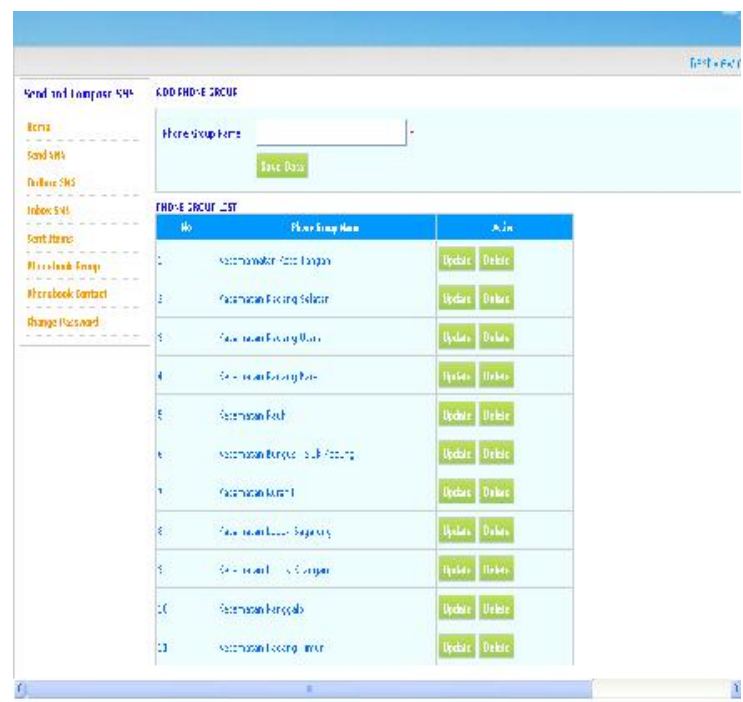

Gambar 6. Halaman Daftar /Kecamatan yang ada di kota Padang dari pada Aplikasi SMS Gateway

Pada halaman daftar Kecamatan yang ada di kota Padang, admin bisa menghapus dan menambah data kecamatan.

\section{Penutup}

\section{a. Kesimpulan}

Dalam penelitian ini peneliti baru sampai pada tahap pengiriman sms kepada pelanggan, sms yang diterima dapat dilihat dalam penelitian berikut ini dan juga perlu diketahui bagi pembaca dan peneliti selanjutnya dimana koding ini ditulis dalam bahasa Pemrograman PHP dan akan dilanjutkan pada progress dan laporan $100 \%$ yang akan dating

\section{b. Saran}

Aplikasi ini masih sangat sederhana karena keterbatasan waktu dan dana, diharapkan kepada pembaca dan penliti selanjutnya bisa memberikan masukan dan saran guna perbaikan penelitian ini selanjutnya. 


$$
\text { V2.i1(36-44) }
$$

\section{DAFTAR PUSTAKA}

Ali Mustofa, Bambang Genjik Sumartono, Muhammad Basri, Perilaku Konsumen terkait tunggakan rekening listrik golongan Rumah Tangga 450VA pada PLN (Persero), Program Studi Pendidikan Ekonomi FKIP UNTAN, 2012

Chau, P. Y. K., dan P. J. Hu. 2003. Examining a model of information technology acceptance by individual professionals: An exploratory study.

Hoffer, Jeffrey A., George, Joey F., Valacich, Joseph S.,(2005), "Modern System Analysis and Design", The Benjamin / Cumming Publishing Company, Inc.

Jogiyanto H.M, Teknologi Sistem Informasi, 2000, Penerbit Andi Offset, Yogyakarta

Jogiyanto H.M, Sistem Informasi Manajemen, 2000, Penerbit Andi Offset, Yogyakarta

Jogiyanto H.M, Teknologi Sistem Informasi, 2008, Penerbit Andi Offset, Yogyakarta
Jogiyanto. 2008. Metodologi Penelitian Sistem Informasi. CV Andi Offset. Yogyakarta

Lilis Endang Wijayanti. 2005. Pengaruh Perilaku Pemakai Terhadap Kinerja Sistem Informasi: Partisipasi Dan Kepuasan Pemakai Sebagai Variabel Independen. Jurnal Pendidikan Akutansi Indonesia. 3 (2): 24-25. http://journal.uny.ac.id/index.php/jpak un/article/.../663.

McLeod Raymond. 2004. Sistem Informasi Manajemen, Edisi Kedelapan. Prenhallindo. Jakarta.

Musa Abu Hasan. 2008. Benefiting ICT for all. Serdang: Universiti Putra Malaysia (UPM) Publisher.

Musa Abu Hasan, Hayrol A.M.S., Jeffrey L.S. 2012. Determinant of information and communication technology usage among village administrators in Malaysia using Extended Technology Acceptance Model. Research Journal of Applied Sciences. 7(8): 370-381.

Sanggala, 2007, E., Aplikasi SMS Dengan VB dan Mobile FBUS 1.5 ActiveX Control. Bandung: Universitas Pasundan Bandung.

Teguh Wahyono, 2008, Sistem Informasi (Konsep Dasar, Analisis Desain dan Implementasi)

- Yogyakarta: Penerbit Graha Ilmu 